\title{
PERFORMANCE OF LAYING HENS FED GRADED LEVELS OF DRIED YELLOW COCOYAM CORM MEAL (Xanthosoma sagittifolium) AS PARTIAL REPLACEMENT FOR MAIZE
}

\author{
OKONKWO, V.N. \\ Department of Animal Science and Fisheries, Faculty of Agriculture and Veterinary \\ Medicine, Imo State University P.M.B 2000 Owerri, Imo State, Nigeria.
}

\section{E-mail: veronicaokonkwo69@gmail.com}

\begin{abstract}
Yellow cocoyam (Xanthosoma sagittifolium), a tropical root crop is presently underutilized as energy feedstuff in poultry diets. The objective of this experiment was to evaluate the effects of dried cocoyam corm meal as partial replacement for maize on egg laying and haematological parameters of layer hens. Fifty-six (56) days feeding trial was conducted using one hundred and twenty (120) Isa brown layer hens of twenty weeks (20 weeks) old. Sample of the cocoyam corm meal used for this study was analyzed in the laboratory to determine its proximate nutrient composition. Results showed moisture content 79\%, ash 4\%, fat $1.1 \%$, fibre $5.5 \%$, carbohydrate $24 \%$, protein $8.05 \%$ and energy $3160.05 \mathrm{kcal} / \mathrm{kg} \mathrm{DM}$. The cocoyam corm meal was used to formulate layer hens' diets: $T_{1}, T_{2}, T_{3}$, and $T_{4}$ at $0 \%, 10 \%$, $15 \%$ and $20 \%$ inclusion levels respectively. The experimental layer hens were divided into four treatment groups of thirty (30) hens each which was further replicated three times, ten (10) birds per replicate in a Completely Randomized Design (CRD). Each group of the experimental birds was subjected to one of the experimental diets for the period of 56 days and drinking water was also provided regularly. At the expiration of the experiment, three (3) birds were selected from each group for haematological parameters evaluation. Average daily feed and total feed intake showed no significant $(P>0.05)$ difference though $T_{4}$ was higher $(P<0.05)$ among the treatments and $T_{1}$ was the least $(P<0.05)$. Total body weight gained was significantly $(P<0.05)$ higher at $T_{4} . T_{2}$ was significantly $(P<0.05)$ the lowest among other treatments. $T_{1}$ had a significant $(P<0.05)$ highest hen day egg production followed by $T_{2}$ and $T_{3}$ which were statistically the same $(P>0.05)$ while $T_{4}$ had the lowest $(P<0.05)$ among the treatments. $T_{2}$ had the heaviest $(P<0.05)$ egg weight of $65.40 \mathrm{~g}$ while $T_{1}$ had the lowest $(P<0.05)(61.76 \mathrm{~g})$ though still within the same category of large in USDA (2000) egg weight rating. Feed efficiency of feed/g egg weight was higher at $T_{2}(1.27) . T_{4}$ (1.38) had the lowest $(P<0.05)$ feed conversion efficiency with no significance $(P>0.05)$ difference among values obtained from other treatments. $T_{1}$ had the highest pack cell volume $(P<0.05)$. Red blood cell, count, haemoglobin and white blood cell count values which did not differ significantly $(P>0.05)$ among the values of $T_{2}$, followed by $T_{3}$. Results obtained in the haematological parameters evaluated showed significant difference $(P<0.05)$ recorded in some values; $T_{3}$ had the highest haemoglobin (20.46 pg) followed by $T_{4}\left(20.34 \mathrm{pg}\right.$ ), $T_{1}$ had the least $(19.80 \mathrm{pg})$ but still within the recommended range for layer hens for optimal
\end{abstract}

Journal of the Faculty of Agriculture and Veterinary Medicine, Imo State University Owerri website: www ajol.info/index.php/jafs

Open Access article distributed under the terms of the Creative Commons License CC BY-NC 
Volume 18, Number 1, April, 2020 pp 27 - 39

performance. It is concluded that dried cocoyam corm meal (Xanthosoma sagittifolium) is an ideal ingredient in layer hens diets up to $15 \%$ inclusion level for good performance.

Key words: Egg production, growth, haematology, proximate composition.

https://doi.org/10.4314/jafs.v18i1.3

\section{INTRODUCTION}

Steady increase in cost of conventional poultry feedstuffs in Nigeria has led to search and utilization of alternative feed sources for poultry (Obidimma, 2009; Esiegwu and Okonkwo, 2018). Inadequate production of maize which is the major conventional energy feed source to meet the energy requirements for man, livestock and raw material for industries Anyaehie, (2006), created the need to look for cheaper, readily available and alternative sources of energy feedstuff for poultry such as yellow cocoyam corm known as "ede uhie" in Igbo (Ndimantang et al., 2006).

Cocoyam is a collective name for species of Colocasia and Xanthosoma genera from family of Aracea (Opara, 2003, Ramanatha et al., 2010). Cocoyam is a herbaceous annual and perennial crop with underground roots known as corms which contains high amount of starch (Ramanatha et al., 2010).

Xanthosoma sagittifolium is very nutritious and highly productive and yet it's corms and cormels are being under utilized as energy feed resources (Onu et al., 2006, Owusu-Darko et al., 2014, Eyasu et al., 2019).

The cocoyam corm can be processed into fufu and the cormels can also be used in soup thickening or serve as portage with vegetables in Igbo land (Onu et al., 2006). It is also a source of dietary energy, proteins, vitamins and as well high in potassium, zinc and nicotic acid (Aboubakar et al., 2008).

Cocoyam corms contains anti-nutritional factors such as tannins, hydrocyanid, oxalates, antitrypsin inhibitor (Okereke, 2012; Hand and Binh, 2013). The anti-nutritional factors in the cocoyam corms could be removed through drying, fermentation, cooking and toasting to make the product safe for human and livestock consumption (Ndimantang et al., 2006, Eyasu et al., 2019).

Ndimantang et al. (2006), Aboubakar et al. (2008), Akinmutimi et al. 2006), Chandra Subhash et al. (2012) observed that Xanthosoma sagittifolium corm meal proved to serve as good food for both man and livestock with its appreciable nutritional profile and higher productivity. Ndimantang et al. (2006) went further to say that cocoyam corm flour (Xanthosoma sagittifolium) contains about 132 calories in a cup of dried and ground corms of 135 grams, $0.347 \mathrm{mg}$ copper, $0.32 \mathrm{mg}$ of vitamin B6, $31.9 \mathrm{gm}$ of carbohydrates, $8.07 \mathrm{mg}$ of potassium, $1.32 \mathrm{mg}$ of iron, $1.131 \mathrm{mg}$ of vit. B1, $0.257 \mathrm{mg}$ of manganese and $9.74 \%$ protein.

Owusu - Darko, et al. (2014), evaluated the potentials of cocoyam corms and cormels and expressed dismay for an under utilization and under exploitation of this arable crop by consumers. However, Iwuoha et al. (1995), Sheila (1999), Dosumu, et al. (2012), Zhu, Journal of the Faculty of Agriculture and Veterinary Medicine, Imo State University Owerri website: www ajol.info/index.php/jafs

Open Access article distributed under the terms of the Creative Commons License CC BY-NC 
Volume 18, Number 1, April, 2020 pp 27 - 39

(2016) reported some anti-nutritional factors in cocoyam corms and cormels especially calcium oxalate and physico-chemical properties which can hinder their utilization as food if not well processed. In other to proffer solutions to these problems posed by these antinutritional factors of cocoyam corms and cormels, Sefa et al. (2004), observed that calcium oxalate, tannin, hydrocyanid etc could be removed through good processing methods such as drying, soaking or cooking and could make the corm meal safe for consumption and for other industrial uses.

Matikiti, (2017), observed that the proximate nutritional composition of cocoyam were in the range of $65-78 \%$ moisture $2-5 \%$ ash, $0.2-1.10 \%$ fat, $2.5-5 \%$ fibre, $14-23 \%$ carbohydrates, $390-460 \mathrm{mg} / 100 \mathrm{~g}$ potassium, $24-43 \mathrm{mg} / 100 \mathrm{~g}$ calcium, 79-91 kcal/cal energy, $4.8 \%$ protein and $79-110 \mathrm{mg} / 100 \mathrm{~g}$ magnesium.

The study was therefore targeted to investigate the performance and haematological parameters of laying hens fed cocoyam corm meal (Xanthosoma sagittifolium) as partial replacement for maize in their diets.

\section{MATERIALS AND METHODS}

This research was conducted at the Teaching and Research Farm, Imo State University Owerri, located within the South-East agro-ecological zone of Nigeria. Owerri lies between latitude $5^{0} 29^{\prime}$ North and longitude $7^{0} 20^{\prime}$ East, $91 \mathrm{~m}$ above sea level with temperature and humidity ranging from $20.0-27.5^{\circ} \mathrm{C}$ and $75-90 \%$ and rainfall annually ranging from $1,500 \mathrm{~mm}$ to $2,200 \mathrm{~mm}$, (AccuWeather, 2015).

The corms of Xanthosoma sagittifolium, used for this experiment were bought from Umucheke Okwe in Onuimo Local Government Area of Imo State. The corms were peeled, washed, cut into pieces and sundried for 15 days so that it could be crispy while milling using a hammer mill. The dried cocoyam corm meal (DCCM) was taken to the laboratory for proximate analysis according to AOAC, (2010). Four layer diets; $\mathrm{T}_{1}$ (control), $\mathrm{T}_{2}, \mathrm{~T}_{3}$ and $\mathrm{T}_{4}$ were formulated in which dried cocoyam corm meal was added to partially replace maize at $0 \%, 10 \%, 15 \%$ and $20 \%$ respectively. The experimental diets and their calculated nutrients composition are shown in Table 1.

One hundred and twenty (120), 20 weeks old Isa brown pullets at point of lay were bought from a reputable dealer in Ibadan and were used for the experiment. The birds were separated into four treatment groups of 30-layer hens and each group was further subdivided into three replicates of 10-layer hens each housed in a pen measuring $2.4 \mathrm{~m} \times 1.5 \mathrm{~m} \times 1.8 \mathrm{~m}(\mathrm{H} \mathrm{x} \mathrm{L} \mathrm{x} \mathrm{W})$. The birds were fed commercial layer mash for one week for stabilization after which the groups were assigned to the four experimental diets in a Complete Randomized Design (CRD) and the initial weights of the birds recorded. Feed and water were provided adlibitum and other routine management of laying hens was also observed, (Opara, 2003). Egg were collected three times a day, morning, afternoon and evening, and recorded.

Feed intake was recorded daily and was determined by weighing the quantity of feed offered and the left over the following day, the difference between the two values was the daily feed intake. The body weight gain was observed by weighing the birds every week with electronic

Journal of the Faculty of Agriculture and Veterinary Medicine, Imo State University Owerri website: www ajol.info/index.php/jafs

Open Access article distributed under the terms of the Creative Commons License CC BY-NC 
Volume 18, Number 1, April, 2020 pp 27 - 39

digital scale to determine their body weight change. The feed conversion ratio of the birds was determined on the weight of the egg laid by dividing the total feed intake by the total egg weight.

Hen day egg production was also determined by dividing the total number of eggs laid per day by the total number of birds alive and multiple by hundred:

$$
\frac{\text { Total number of egs laid/ day }}{\text { Number of birds alive }} \times \frac{100}{1}
$$

(Brown et al., 2000, Anyaehie, 2006).

All eggs collected from each group were weighed daily with electronic digital scale to determine the average egg weight. Blood samples were collected from three (3) birds per treatment at the end of the experiment from their wing web using syringe and needle. The blood samples collected were poured into specimen bottles containing EDTA (Ethylene diamine tetra acetic acid) for haematological analysis according to Dacie et al. (1984) and Merck Manual, (2012).

All data collected were subjected to analysis of variance according to AOAC (2003), using SPSS, (2012) and significantly different means were separated using Duncan's New Multiple Range Test (DNMRT) of the same software.

\section{RESULTS AND DISCUSSION}

Table 2 shows the proximate analysis of dried cocoyam corm meal (Xanthosoma sagittifolium) used for this study. The crude fibre, crude protein, ash, ether extract moisture, dry matter, nitrogen free extract and metabolizable energy are: $5.56 \%, 8.05 \%, 4.00 \%, 4.5 \%$, $79 \%, 80.05 \%, 48.0 \%$ and $3160.05 \mathrm{kcalkgDm}$ respectively. These values were in line with the values obtained by Sarla et al. (2012) and Makikiti, (2017).

The result of the performance of layer hens fed dried cocoyam corm meal are shown in Table 3. Feed intake increased as the levels of dried cocoyam corm meal increased in the diets though there were no significant $(\mathrm{P}>0.05)$ difference among the treatment groups, $\mathrm{T}_{4}$ had the highest $(\mathrm{P}<0.05)$ feed intake among other groups while $\mathrm{T}_{1}$ had the least $(\mathrm{P}<0.05)$. The results of feed intake obtained in this study are in agreement with observations of Esonu $\left(2000^{\mathrm{a}}\right.$ and $2000^{b}$ ), Ndimetang et al. (2006) who reported that cocoyam corm meals were very rich in nutrients and very palatable and therefore increases its acceptability in poultry diets. On body weight gain, hens placed on diets $2\left(\mathrm{~T}_{2}\right)$ had significance $(\mathrm{P}<0.05)$ least weight gain among the treatment groups, $\mathrm{T}_{1}$ group and $\mathrm{T}_{3}$ were the same $(\mathrm{P}>0.05)$ while $\mathrm{T}_{4}$ had the highest $(\mathrm{P}<0.05)$ weight gain among other groups. This obviously implies that cocoyam corm meal (Xanthosoma sagittifolium) improved adequate weight gain that are required for maximum egg production. This is in agreement with Kekeocha and Okonkwo (2012) who stated that growth require synthesis of new body tissues and the raw materials for growth have to be provided through feed and feedstuffs that are adequate for it. In laying hens that are reared for other purposes, production however is influenced by growth which has to be attained to a 
Volume 18, Number 1, April, 2020 pp 27 - 39

particular point (1.5 to $2 \mathrm{~kg}$ ). On hen day egg production, the layer hens fed $0 \%$ dried cocoyam corm meal $\left(\mathrm{T}_{1}\right)$ had the highest egg production $(72.02 \%)$ which was significantly $(\mathrm{P}<0.05)$ higher than $\mathrm{T}_{4}(57.03 \%), \mathrm{T}_{2}$ and $\mathrm{T}_{3}$ had same $(\mathrm{P}>0.05)$ number of eggs $(67.26 \%)$ which was closer to $\mathrm{T}_{1}$. Egg production reduced as cocoyam corm meal increased the diets, this could be attributed to higher weight gain observed at higher level inclusion of cocoyam corm meal in the diets of layer hens. This inference affirmed the claim of Ikpe et al. (2019) who stated that too much weight in layer hens resulted to low egg production. Moreso, higher feed intake of $\mathrm{T}_{4}$ hens did not match the egg production value recorded in this study. On egg weight, $\mathrm{T}_{2}(10 \% \mathrm{DCCM})$ was significantly $(\mathrm{P}<0.05)$ higher than other groups with an average weight of $(65.40 \mathrm{~g})$ followed by $\mathrm{T}_{3}(64.36 \mathrm{~g}), \mathrm{T}_{1}$ (control) had the lowest $(61.76 \mathrm{~g})(\mathrm{P}<0.05)$ which was significantly the lowest $(\mathrm{P}<0.05)$ among other groups on egg weight. This experiment showed that $15 \%$ inclusion of cocoyam corm meal supported egg production, egg weight and feed efficiency more than $20 \%$ inclusion $\left(\mathrm{T}_{4}\right)$. On feed conversion efficiency, $\mathrm{T}_{2}$ had the highest $(\mathrm{P}<0.05)(1.27)$ among other groups followed by $\mathrm{T}_{1}(1.31)$ and then $\mathrm{T}_{4}(1.38)$ which had the lowest $(\mathrm{P}<0.05)$, though there were no significant $(\mathrm{P}>0.05)$ difference among the treatment groups on feed conversion ratio. This is in line with Iheukwumere et al. (2008) and Esonu, (2000b) who stated that layer hens' diets should be adequate with regard to essential nutrients to improve feed efficiency and feed utilization. Also, Effiong et al. (2015), Singh et al. (2015) reported positive influence on hen day production, egg weight and feed efficiency on hens fed adequate diets in terms of quality and quantity. All the eggs obtained in this study were within the same category as stated in the United States, Department of Agriculture (2000 and 2013) as standard for egg weight and hen day production. It is important to state here that as at the time this experiment was carried out, very little information was available on the inclusion of yellow cocoyam corm meal Xanthosoma (sagittifolium) as feed ingredient in layer hens' diets.

The results of haematological analysis of layer hens fed dried cocoyam corm meal are shown in Table 4.

Haematological parameters such as haemoglobin, packed cell volume, red blood cell volume tend to decrease as the levels of cocoyam corm meal increased in the diets but did not follow a definite order.

Moreso, all the values obtained were within the normal range for hens which were in line with Merck, (2012). The mean cell haemoglobin concentration increased $(\mathrm{P}<0.05)$ for hens fed high inclusion levels of cocoyam corm meal in their diets. $\mathrm{T}_{3}$ had the highest $(\mathrm{P}<0.05)$ cell haemoglobin concentration (20.46pg) followed by $\mathrm{T}_{4}(20.34 \mathrm{pg})$ which differed significantly $(\mathrm{P}<0.05)$ from $\mathrm{T}_{1}(19.80 \mathrm{pg})$. The white blood cell count values did not differ significantly $(\mathrm{P}>0.05)$ among the treatment groups and all the values obtained are within the recommended range for avian specie also in line with Merck, (2012). Other blood parameters evaluated include; Eosinophil, Monocytes, Rasophil showed no significant ( $\mathrm{P}>0.05)$ difference among the treatment groups. These indicate the normal body functions of hens and the absence of infection in all the treatment groups. This is in line with Awuyobi et al. (2002), (Ewuola et al., 2004), Iheukwumere et al. (2006) who stated that haematological parameters are an index and reflection of the effects of dietary treatment on the animal in Journal of the Faculty of Agriculture and Veterinary Medicine, Imo State University Owerri website: www ajol.info/index.php/jafs

Open Access article distributed under the terms of the Creative Commons License CC BY-NC 
Volume 18, Number 1, April, 2020 pp 27 - 39

terms of type quality and quantity ingested to meet the physiological, biological, biochemical and metabolic necessities of the body.

In this study, none of the haematological parameters evaluated had any adverse effect on the layer hens as well as egg production, and an indication that the dried cocoyam corm meal is an ideal feed ingredient and could replace maize in layer hen's diets up to $15 \%$ level in their diets without any deleterious effect on the overall performance.

\section{CONCLUSION AND APPLICATION}

\section{It was concluded that:}

1. Feeding layer hens with dried cocoyam corm meal (Xanthosoma sagittifolium) based diets improved feed intake, body weight gain, egg weight and feed conversion efficiency.

2. Hen day egg production of hens placed on $15 \%$ cocoyam corm meal was close to the value obtained from the control $\left(\mathrm{T}_{1}\right)$ which was the highest.

3. For poultry farmers and poultry nutritionists whose target is primarily on improvement of feed efficiency and egg weight of laying hens, the result of this study showed that $10 \%$ dried cocoyam corm meal replacement of maize will meet that need, hence, it is recommended.

4. Finally, on a general note, the result of this study showed that $15 \%$ of cocoyam corm meal (Xanthosoma sagittifolium) could be included in the diets of layer hens without any adverse effects on the performance and blood parameters. 


\section{REFERENCES}

Aboubakar, N. Njinteng, Y.N. Schar, J. and Mbofung, C.M.F. (2008). Physico-chemical internal properties and micro-structure of six (6) varieties of taro (Colocasia esculenta flours and starches). Journal of Food Engineering 86(2) 294-305. http://dx.doi.org/10/016:Foodeng.2007.10.006.links.

Accu Weather, (2015): Weather for Owerri, Imo State, Nigeria.https://www.accuweather.com

Agrited (2007). Agricultural International Technology and Trade (Nig.) Ltd. A Complete Ration of Vitamins and Trace Minerals for layer and broiler birds, Victoria Island Lagos, Nigeria.

Akinmutimi, A.H., Amaechi, N., Onogu, M., (2006). Evaluation of raw African yam bean meal as substitute for soya bean meal in the diets of weaner rabbits. Journal of Anim. Vet. Adv., 5(11): 907-911.

Anyaehie, A.A. (2006). Studies on exogenous enzyme supplementation of high fibre (maizecob) soyabean based poultry diets: Ph.D Thesis, Imo State University, Owerri, Nigeria.

AOAC, (2003). Official Methods of Analysis (17 $7^{\text {th }}$ ed.) Association of Official Analytical Chemists $2^{\text {nd }}$ Rev. Vol. (1). Gathering AOAC like.

AOAC, (2010). Official Methods of Analysis. 19 ${ }^{\text {th }}$ ed. Association of Official Analytical Chemists. Washington D.C. USA.

AOAC, (2012). Official methods of Analysis Association of official analytical chemists $20^{\text {th }}$ ed. Washington D.C.

Awujiobi, H.A. and Opia, G.O. (2002). The effect of psychological status on some blood parameters of the Newzea Land White Doe Rabbits. Proc. of $7^{\text {th }}$ Annual Conf. of Anim. SC. Assoc. of Nigeria, (ASAN) Sept., $16^{\text {th }}$ to $19^{\text {th }} 2002$, University of Agric. Abeokuta.

Brown, A.A., Ajayi, S. A. and Fala, S.A. (2000). Effect of supplementation of layers diets with mixture of different pepper species on egg quality. Nigeria Journal of Anim. Prod. 27(1), 2000:71-79.

Chandra Subbash, Saklani Sarla, Singh Jaybandhan (2012). Phyto-chemical Screening of GARHWAL HIMALAYA wild edible tuber Colocasia esculenta. Research Journal of Paramcy, ISSN 22308407.

Dacie, T.F. and Lewis, S.M. (1984). Practical Haematology $6^{\text {th }}$ ed. Churchill, New York. Pg. 24-36.

Dosumu, O.O., Oluwaniyi, O.O. Awolola, G.V., Bashiru, M.O. and Oyedeji, O.O. Antimicrobial properties of three Nigerian condiments. Nigeria Food Journal, Official. Journal of Nigeria Institute of Food Science and Technology, 30(1): 43-52. 
Volume 18, Number 1, April, 2020 pp 27 - 39

Effiong, O.O., William, M.E. and Eyoh, G.D. (2015). Laying performance and egg quality evaluation of pullets fed diets containing graded levels of processed Horse eye bean (Mucuna urens) meal. Journal of Agriculture and Life Sciences, 2(1:)140-145.

Esiegwu, A.C. and V.N. Okonkwo (2018). Growth performance and blood indices of finisher broiler birds fed enzyme fortified (maxi-grain) rice milling waste. Journal of Agriculture and Food Sciences, 16(1): 24-32.

Esonu, B.O. (2000a). Animal Nutrition and Feeding: A Functional Approach. Rukzed and Rucksons Associates Owerri, Nigeria.

Esonu, B.O. (2000b). Effect of dietary cooked wild variegated cocoyam (Caladium hortulanium) on performance of broiler chickens. Tropical Agriculture, 77(4):269271

Ewuola, E.O., Folayan, O.A., Gbore, F.A. Adewumi, A.L., Akanji, R.A., Ogunlade, J.T., Adeneye, J.A. (2004). Physiological response of growing West African dwarf goats fed groundnut shell-based diets as the concentrate supplements. Bowen J. Agric. 1(1): pp. 61-69.

Eyasu, W. Tileye, T. and Kassahu, T. (2019). Proximate mineral and anti-nutrient contents of cocoyam (Xanthosoma sagittifolium) (L.) Schott. International Journal of Food Science, https://doi.org/10.1155/2019/8965476.

Hang, D.T. and L.V. Binh, (2013). Oxalate concentration in taro leaves and petioles and effect of added calcium on nitrogen retention in pigs given diets containing $50 \%$ ensiled taro leaves and petioles. Livestock Research for Rural development, 25, 65, http://www.Irrd.org/Irrd25/4/hang25065.htm.

Iheukwumere, F.C. Ndubuisi, E.C., Mazi, E.A. and Onyekwere, M.U. (2008). Performance Nutrient Utilization and Organ characteristics of broiler finishers fed cassava leaf meal (Manihot esculenta Crantz). Pakistan Journal of Nutrition, 7(1):13-16.

Iheukwumere, F.C., Abu, A.H. and Amech, M. (2006). Effect of human menopausal gonadoropin on haematoogical and serum biochemical parameters of the Nigerian Indigenous chickens. International Journal of Poultry Science 5(7): 632-634.

Iheukwumere, F.C., Abu, A.H. and Ameh, M. (2006). Effect of human menopausal gonadotropin on haematological and serum biochemical parameters of the Nigerian indigenous chicken. Int. Journal of Poultry Science 5(7):632-634.

Ikpe, J.N. Madubuike, F.N. Ndubuisi, E.C. Okorie, K.C., Esiegwu, A.C., Okonkwo, V.N. and Oko, E.C. (2019). Effect of cooked Mucuna sloanei seed meal on the performance and egg quality characteristics of laying hen. Nigerian Society for Animal Production. Annual / Conf. Abuja.

Iwuoha, C.I. and Kalu, F.A. (1995). Calcium oxalate and physico-chemical properties of cocoyam (Colocasia esculenta and Xanthosoma sagittifolium) tuber flours as affected by processing J. of Food Chemistry vol. 54(1). Pp. 61-66. 
Volume 18, Number 1, April, 2020 pp 27 - 39

Kekeocha, C.C. and V.N. Okonkwo, (2012). Animal Nutrition in the tropics. Sibon books Ltd Lagos Nigeria. Pp. 24-35.

Matikiti, A. Allemann, J., Kujeke, G. Gasura, E., Masekesa, T. and Chabata, I. (2017). Nutritional Composition of Cocoyam (Colocasia esculenta) Asian Journal of Agriculture and Rural Development, vol. 7(3). Pp., 48-55.

Merck, Veterinary Manual (2012). Haematological Reference Ranges. Retreived November 18, 2019, from: http://www.merckmanual.com.

Ndimantang, B.C., O. Asinobi, N. Obiakor, (2006). The effect of different processing method on some anti-nutritional factors content of Ede Uhie (Xanthosoma sagittifolium) and edeocha (Colocasia esculenta). Int. Journal of Agriculture and Rural Development, 7(2), 7-14.

Obidinma, V.N. (2009). Brewer's dried grain as energy source in poultry production. A Ph.D. Thesis, Imo State University, Owerri, Nigeria.

Okeke, C.O. (2012). Utilization of Cassava, sweet potato and cocoyam meals as dietary sources for poultry. World Journal of Engineering and Pure Applied Sciences, 2(3): 63-68.

Onu, P.N. and F.N., Madubuike (2006). Effect of Raw and Cooked Wild Cocoyam (Caladium bicolor) on the performance of broiler chicks. Int. Journal of Poult. Sc. 39:268-273.

Opara, L.U. (2003). Edible Aroids Post-harvest operation in: Post - Harvest Compendium, Massey University Food and Agricultural Organization of the United Nations, Rome: Italy-Google Scholar.

Owusu-Darko, P.G., Paterson, A. and Omenyo, E.L. (2014). Cocoyam (corms and cormels) an under exploited food and feed resource. Journal of Agricultural Chemistry and Environment, 03(01), 22-29.

Ramanatha, R.V., P.T. Mathews, P.B. Eyzaguire and D. Hunter, (2010). The global diversity of taro: Ethinobotany and Conservation. Rome Italy: Biodiversity International. Google Scholar.

Sarla, S. Sublash, C. Kothiyal, Singh, J. (2012). Phyto-chemical screening of Garhwali Himalaya wild edible tuber (Colocosia esculenta). Int. Research Journal of Pharmacy, 3(3) 181.

Sefa Dedeh, S., and E.K. Agyir Sackey, (2004). Chemical Composition and the effect of processing on oxalate content of cocoyam (Xanthosoma sagittifolium) and Colocasia esculenta cormels. Food Chemistry, 85, 479-487. Crossing CAS Web of Science @ Google Scholar.

Sheila, C.N. and Geoffrey, S. (1999). Oxalate Content of Foods and its effect on humans. Asia Pacific Journal of Clinical Nutrition 8(1) 64-74. 
Volume 18, Number 1, April, 2020 pp 27 - 39

Singh, V., Tyagi, P.K., Mandal, A.B., and Singh, S. (2013). Reducing egg cholesterol through dietary addition of ginger and garlic in quails. Indian Journal of Poultry Science, 48(3): 306-312.

SPSS, (2012). Statistical Package for Social Science, Version 21 USA. IBM Corporation.

USDA, (2000). United States Department of Agriculture, (2000). Egg-grading Manual. Agricultural Marketing Service, Agricultural Handbook Number 75.

USDA, (2013). United States Department of Agriculture. Nigeria Poultry and Products. Retrieved from: http://gain.fas.usda.gov/gainfiles/200211/145.pdf.

Zhu, F. (2016). Buck wheat Starch: Structure, Properties and Applications. Journal of Trends in Food Science and Technology, vol. 49, pp. 121-135. 
Volume 18, Number 1, April, 2020 pp 27 - 39

\section{APPENDIX}

Table 1: Ingredient and Calculated Nutrient Compositions of the experimental diets

\begin{tabular}{lcccc}
\hline \multicolumn{1}{c}{ Ingredients } & $\begin{array}{c}\mathbf{T}_{\mathbf{1}} \\
(\mathbf{0 . 0 \%})\end{array}$ & $\begin{array}{c}\mathbf{T}_{\mathbf{2}} \\
(\mathbf{1 0 \%})\end{array}$ & $\begin{array}{c}\mathbf{T}_{\mathbf{3}} \\
(\mathbf{1 5 . 0 \%})\end{array}$ & $\begin{array}{c}\mathbf{T}_{\mathbf{4}} \\
(\mathbf{2 0 . 0} \boldsymbol{)})\end{array}$ \\
\hline Maize & 50.0 & 40.0 & 35.0 & 30.0 \\
Cocoyam corm meal & 0.0 & 10.0 & 15.0 & 20.0 \\
Soya bean meal & 16.0 & 16.0 & 16.0 & 16.0 \\
Fish meal & 3.0 & 3.0 & 3.0 & 3.0 \\
Blood meal & 1.0 & 1.0 & 1.0 & 1.0 \\
Wheat offal meal & 10.0 & 10.0 & 10.0 & 10.0 \\
Palm kernel cake meal & 10.25 & 10.25 & 10.25 & 10.25 \\
Bone meal & 9.0 & 9.0 & 9.0 & 9.0 \\
Salt & 0.25 & 0.25 & 0.25 & 0.25 \\
Vit. Premix & 0.25 & 0.25 & 0.25 & 0.25 \\
L- Lysine & 0.15 & 0.15 & 0.15 & 0.15 \\
DL - Methionine & 0.10 & 0.10 & 0.10 & 0.10
\end{tabular}

\section{Calculated Nutrient Composition of Experimental Diets}

$\begin{array}{lcccc}\text { Crude protein }(\%) & 17.96 & 17.55 & 17.35 & 17.22 \\ \text { Crude fibre }(\%) & 4.14 & 4.10 & 4.04 & 4.00 \\ \text { Ether extract }(\%) & 3.70 & 3.56 & 3.45 & 3.25 \\ \text { Calcium }(\%) & 3.55 & 3.60 & 3.68 & 4.00 \\ \text { Phosphorus }(\%) & 1.00 & 1.06 & 1.08 & 1.12 \\ \text { Lysine }(\%) & 0.92 & 0.95 & 1.00 & 1.12 \\ \text { Methionine }(\%) & 0.38 & 0.39 & 0.45 & 0.48\end{array}$

Metabolizable

Energy Kcal/kg

2705.06

2650.05

2625.00

2575.98

To provide; Vitamin $\mathrm{k}=2.5 \mathrm{gm}$, Thiamine $\mathrm{B} 1=1.5 \mathrm{~g}$, Riboflavin $\mathrm{B}_{2}=5 \mathrm{~g}$, Pyriboflavin $\mathrm{B} 6=$ $1.5 \mathrm{~g}$, vitamin B12 $=10 \mathrm{mg}$, Biotin $=20 \mathrm{mg}$, Niacin $=15 \mathrm{gm}$, Pantothemic acid $=5 \mathrm{mg}$, folic acid $=0.6 \mathrm{gm}$, Manganese $=75 \mathrm{gm}$, zinc $=50 \mathrm{gm}$, Iron $=25 \mathrm{gm}$, copper $5 \mathrm{gm}$, Iodine $=1 \mathrm{gm}$, Selenuim $=100 \mathrm{gm}$, Cobalt $=300 \mathrm{mg}$, chlorine chloride $=150 \mathrm{gm}$.

Source: Agrited, (2007). 
Volume 18, Number 1, April, 2020 pp 27 - 39

Table 2: Proximate Composition of Cocoyam Corm Meal (Xanthosoma sagittifolium)

\begin{tabular}{ll}
\hline Nutrient \% DM & Composition \\
\hline Crude fibre & 5.56 \\
Crude protein & 8.05 \\
Ash & 4.00 \\
Ether extract & 4.5 \\
Moisture & 79 \\
Dry matter & 80.05 \\
Nitrogen Free Extract & 48.00 \\
ME (Kcal/kg) & $3160.05 \mathrm{kcal} / \mathrm{kgDM}$ \\
\hline
\end{tabular}

Table 3: Performance of layer hens fed sun dried cocoyam corm meal (DCCM)

\begin{tabular}{|c|c|c|c|c|c|}
\hline \multirow[b]{2}{*}{ Parameters } & \multicolumn{4}{|c|}{ Dietary Treatment } & \multirow[b]{2}{*}{ SEM } \\
\hline & $\begin{array}{c}\mathbf{T}_{1} \\
(\mathbf{0 \%})\end{array}$ & $\begin{array}{c}T_{2} \\
(10 \%)\end{array}$ & $\begin{array}{c}T_{3} \\
(15 \%)\end{array}$ & $\begin{array}{c}\mathbf{T}_{4} \\
(20 \%)\end{array}$ & \\
\hline Initial body weight(g) & 1710.00 & 1733.33 & 1710.00 & 1693.33 & 10.50 \\
\hline Total body weight gain(g) & $96.67^{\mathrm{b}}$ & $66.67^{\mathrm{c}}$ & $96.67^{\mathrm{b}}$ & $100.00^{\mathrm{a}}$ & 11.12 \\
\hline Final body weight(g) & $1806.67^{\mathrm{a}}$ & $1800.00^{\mathrm{b}}$ & $1806.67^{\mathrm{a}}$ & $1793.33^{c}$ & 16.18 \\
\hline Av. daily feed intake(g) & $113.50^{\mathrm{d}}$ & $114.00^{c}$ & $114.50^{\mathrm{b}}$ & $1150.01^{\mathrm{a}}$ & 0.25 \\
\hline Total feed intake $(\mathrm{g})$ & $3405^{\mathrm{d}}$ & $3420^{c}$ & $3435^{\mathrm{b}}$ & $3450.3^{\mathrm{a}}$ & 0.36 \\
\hline Hen day egg production( $\%)$ & $72.02^{\mathrm{a}}$ & $67.26^{\mathrm{b}}$ & $67.26^{\mathrm{b}}$ & $57.03^{\mathrm{c}}$ & 1.11 \\
\hline Av. N0. of eggs/bird within 56 days & 45.20 & 41.10 & 41.10 & 40.02 & 0.05 \\
\hline Av. Egg weight(g) & $61.76^{\mathrm{d}}$ & $65.40^{\mathrm{a}}$ & $64.36^{\mathrm{b}}$ & $62.36^{\mathrm{c}}$ & 2.57 \\
\hline Total egg weight(g) & 2606.272 & 2687.94 & 2581.48 & 2495.65 & 0.04 \\
\hline Feed conversion ratio (gfeed/g egg wt) & 1.31 & 1.27 & 1.33 & 1.38 & 0.03 \\
\hline
\end{tabular}

Means in the same row having different superscripts are significantly different $(\mathrm{P}<0.05)$

SEM: $\quad$ Standard error of mean

DCCM: $\quad$ Dried cocoyam corm meal

gfeed/g egg wt: Gram feed per gram egg weight

Journal of the Faculty of Agriculture and Veterinary Medicine, Imo State University Owerri website: www ajol.info/index.php/jafs

Open Access article distributed under the terms of the Creative Commons License CC BY-NC 
Table 4: Haematological parameters of layer hens fed sun-dried cocoyam corm meal

\begin{tabular}{lccccc}
\hline \multicolumn{1}{c}{ Parameters } & $\begin{array}{c}\mathbf{T}_{\mathbf{1}} \\
(\mathbf{0 \%})\end{array}$ & $\begin{array}{c}\mathbf{T}_{\mathbf{2}} \\
(\mathbf{1 0 \%})\end{array}$ & $\begin{array}{c}\mathbf{T}_{\mathbf{3}} \\
(\mathbf{1 5 \%})\end{array}$ & $\begin{array}{c}\mathbf{T}_{\mathbf{4}} \\
(\mathbf{2 0 \%})\end{array}$ & $\mathbf{S E M}$ \\
\hline Haemoglobin (g/dl) & $13.20^{\mathrm{a}}$ & $12.97^{\mathrm{ab}}$ & $12.40^{\mathrm{b}}$ & $12.57^{\mathrm{ab}}$ & 0.13 \\
Packed Cell Volume (\%) & $43.33^{\mathrm{a}}$ & $41.33^{\mathrm{ab}}$ & $38.00^{\mathrm{c}}$ & $39.00^{\mathrm{bc}}$ & 0.73 \\
Red blood cell (x10 $/ \mathrm{L})$ & $13.33^{\mathrm{a}}$ & $13.07^{\mathrm{ab}}$ & $12.13^{\mathrm{b}}$ & $12.36^{\mathrm{ab}}$ & 0.20 \\
Mean Cell Volume (fl) & 132.50 & 131.17 & 131.33 & 131.27 & 0.23 \\
Mean Cell Haemoglobin (pg) & $19.80^{\mathrm{c}}$ & $19.86^{\mathrm{b}}$ & $20.46^{\mathrm{a}}$ & $20.34^{\mathrm{ab}}$ & 0.12 \\
Mean Cell Haemoglobin & & & & & \\
Concentration (g/dl) & $30.50^{\mathrm{b}}$ & $31.40^{\mathrm{ab}}$ & $32.67^{\mathrm{a}}$ & $32.57^{\mathrm{a}}$ & 0.34 \\
White blood cell & & & & & \\
Concentration (X10 $/ \mathrm{L})$ & $11.93^{\mathrm{a}}$ & $11.77^{\mathrm{ab}}$ & $11.43^{\mathrm{b}}$ & $11.63^{\mathrm{ab}}$ & 0.07 \\
Heterophils (\%) & 53.00 & 53.33 & 53.33 & 52.33 & 0.44 \\
Basophil (\%) & 00.00 & 00.00 & 00.00 & 00.00 & 0.00 \\
Monocyte $(\%)$ & 1.67 & 1.63 & 1.67 & 1.67 & 0.15 \\
Lymphocytes (\%) & 44.00 & 43.67 & 45.67 & 45.00 & 0.34 \\
Eosinophil (\%) & 1.33 & 1.67 & 1.33 & 1.00 & 0.14 \\
ESR (mm $/ \mathrm{hr})$ & 16.67 & 23.33 & 33.33 & 26.67 & 2.89 \\
\hline
\end{tabular}

Means in the same row having different superscripts are significantly different $(\mathrm{P}<0.05)$ 